\title{
Storage Studies on Spray Dried Ripe Banana Powder Produced by Response Surface Methodology
}

\author{
Nimi Barooah ${ }^{*}$, Pranati Das ${ }^{1}$, Mridula Saikia Barooah ${ }^{1}$, \\ Dibya Kant Seth ${ }^{2}$ and Pranab Dutta ${ }^{3}$
}
${ }^{1}$ Department of Food Science and Nutrition, Assam Agricultural University, Jorhat - 13, India ${ }^{2}$ Department of Food Engineering Techology, Tezpur University, Tezpur - 784028, India
${ }^{3}$ Department Plant Pathology, Assam Agricultural University, Jorhat - 785013, India

*Corresponding author

\section{A B S T R A C T}

\begin{tabular}{|l|}
\hline K e y w or d s \\
$\begin{array}{l}\text { Response Surface } \\
\text { Methodology, spray } \\
\text { drying, optimization, } \\
\text { physico-chemical and } \\
\text { organoleptic }\end{array}$ \\
\hline Article Info \\
\hline $\begin{array}{l}\text { Accepted: } \\
\text { 18 May } 2018 \\
\text { Available Online: } \\
\text { 10 June } 2018\end{array}$ \\
\hline
\end{tabular}

The present investigation was aimed at studying the physico chemical, organoleptic and microbial characteristics of the spray dried banana powder across storage produced by Response Surface Methodology. Physico chemical parameters conducted on the optimized powder across three types of packaging materials revealed that moisture content increased significantly at 60 days $(\mathrm{F}=9.50)$ and 90 days $(\mathrm{F}=15.05)$ of storage at $5 \%$ probability level. Reducing sugar depicted a non-significant increase in all the three types of packaging materials. Total sugar content of the banana powder depicted a significant increase at 90 days $(\mathrm{F}=4.08)$. Acidity of the powder declined non significantly across storage whereas browning too depicted a non-significant increase across three types of packaging material. Organoleptic properties in terms of taste and flavor did not have significant effect in the three types of packaging materials. Colour had a significant effect $(\mathrm{F}=5.56)$ on the storability of the banana powder at 90 days of storage. Texture of the optimized banana powder showed a significant change from 30 days of storage in all the three types of packaging materials $(\mathrm{F}=6.33)$. Microbiological assay revealed significant increase in the microbial load in the sample from 30 days of storage at $5 \%$ probability level upto 90 days.

\section{Introduction}

Fruits are considered to be one of the important constituents of human diet, which supply a number of vital nutrients essential to the body. Among them banana is one of the oldest fruits of the world (Mani et al., 2002). Banana is among one of the largest produced and maximum consumed amongst the fruits cultivated in India. India ranks first amongst the banana cultivating countries of the world with an annual production share of 25 per cent of the total harvest (Surendranathan et al., 2003).

Banana when ripened is a soft and delicate fruit with a post-harvest shelf life of 5-10 days. This makes it prone to injury during transport. Further, release of ethylene during bulk storage makes the fruit ripen faster and 
the fruits generally rot before reaching its destination. To prolong shelf life, various processing and preservation methods such as drying, chemical treatments and various packaging methods are used. Drying is the major food processing operation to increase the shelf life. The advantages of a dried extract over conventional liquid forms are lower storage costs, a higher concentration, and the stability of active substances.

Spray drying has been adopted to manufacture powders due to its ability to generate a product with precise quality specifications in continuous operation (Hsu et al., 2003).

Conversion of fruit juice/pulps in to free flowing powders ensures both shelf stability and convenience of use as ready to serve beverages at house hold, or also used any other product requiring fruit solids, such as ice creams, fruit custards, yoghurt, infant formulations, pharmaceutical products etc. The main advantages of fruit juice powders are to increase the shelf life, reduction of volume, reduce packaging and transportation cost and convenience.

Spray dried instant banana milk shake powder has been developed at National Dairy Research Institute, Bangalore. Banana powder obtained by drying fully ripe banana pulp is used in formulations of health food, baby food, tonics, instant banana juice powder, breakfast cereals and flavourings (Evelin et al., 2007). Considering the abundance in production and post-harvest losses of banana at one end and demand for natural nutritious food on the other end, the prospects for manufacture of banana powder have brightened up. Therefore, with the view to utilize the local varieties of banana available in the region spray dried banana powder was produced and hence storage studies were carried out on the spray dried ripe banana powder.

\section{Materials and Methods}

The stage of ripening of banana, have been closely linked with the changes in peel colour and the matching of the peel colour against a set of standard colour plates.

This is a common method used to assess the ripeness of the fruit (Oyewole, 2012). During ripening of banana, there is a tremendous increase in the amount of ethylene produced. This increase is usually accompanied by an increase in respiration rate of the fruit, a phenomenon which is called the climacteric (Shaun and Ferris, 1997). The rate of respiration and ethylene production usually depends on storage temperature, age of fruit and cultivar/hybrid (Medicott et al., 1992).

\section{Selection of sample}

Seven ripening stages of bananas are generally recognized (Li et al., 1997):

Stage 1: green

Stage 2: green, traces of yellow

Stage 3: more green than yellow

Stage 4: more yellow than green

Stage 5: green tip and yellow

Stage 6: all yellow

Stage 7: yellow, flecked with brown.

Hence bananas selected in the present investigation were fully ripe of stage 7 collected from Moina Poria village of Jorhat district of Assam. Bor Jahanji variety (Musa paradisica) owing to its wide availability in the area was selected for the study.

\section{Details of Spray Dryer}

The spray dryer used in the study was a two fluid nozzle spray dryer with peristaltic pump (model LSD-01) available in the Department of Food Engineering and Technology in Tezpur University with the following details: 
Pump: Peristaltic pump

Nozzle: Two fluid

Nozzle diameter: $0.5 \mathrm{~mm}$

Flow accuracy: Better than 1\%

Speed: Adjustable from 1 to 100 RPM

Maximum flow rate: $200 \mathrm{ml} / \mathrm{min}$ (with water @ $25^{\circ} \mathrm{C}$, no pressure no suction)

Head type: Dual roller with spring loaded track

\section{Storage studies of banana powder}

The shelf life of the spray dried banana powder was to be assessed in terms of physico-chemical aspects, organoleptic properties and microbial profile using different packaging materials. Therefore, to fulfill objective of assessing the shelf life of the spray dried banana powder, $20 \mathrm{~g}$ of optimized spray dried banana powder samples were weighed separately, heat sealed and packed in three different packaging materials i.e. aluminium foil laminated pouches (AFLP), low density polyethylene (LDPE) and high density polyethylene (HDPE).

These were then stored at ambient atmosphere for three months (August to November) and at every thirty days intervals the quality parameters such as moisture content, browning index (BI), titratable acidity, total sugar, reducing sugar, organoleptic characteristics and microbial profile were assessed.

\section{Selection of packaging material}

Three types of packaging materials viz., aluminium foil laminated pouch (AFLP), low density polyethylene (LDPE) and high density polyethylene (HDPE) were selected for evaluation of quality of banana powder. The thickness of LDPE and HDPE were 400 and 700 gauge respectively. However, aluminium foil laminated pouch was a coextruded product which consists of inner LDPE, middle aluminium layer and outer polyester layer.

\section{Physico chemical analysis of banana powder}

Studies on physico-chemical aspects i.e., moisture, titratable acidity, non-enzymatic browning, total sugars and reducing sugar was done on the optimised banana powder, the procedures for which are detailed below.

\section{Moisture content}

The moisture content was determined by oven drying method using AOAC (1975) procedure. Five grams of sample was weighed into a previously weighed moisture cup and dried in an oven at $60^{\circ} \mathrm{C}$ till a constant weight was attained.

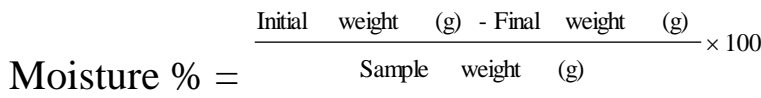

\section{Water activity}

The water activity of the powders was measured using an electronic dew point water activity meter (Aqualab Series 4TE, Decagon Devices, Inc., Pullman, Washington, USA) available in the Department of Food Engineering and technology, Tezpur University.

\section{Total soluble solids (TSS)}

TSS was determined by Hand Refractometer $\left(0-32^{\circ}\right.$ Brix $)$ using the method of Ranganna (2009).

\section{Titratable acidity}

The total acidity of the fresh banana and developed banana powder were determined by titration method. Each of the samples $(10 \mathrm{ml})$ 
was titrated against $0.1 \mathrm{NaOH}$ (standardized using standard oxalic acid) using phenolphthalein indicator. The end point was noted (the colour changed from colourless to pale pink). Total acidity was calculated in terms of citric acid using the following formula (Rekha et al., 2012):

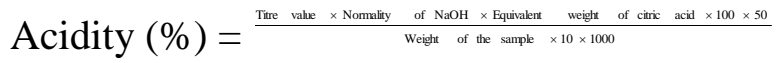

Organoleptic characteristics assessment of banana powder

Taste, flavor, colour, texture and overall acceptability of the optimized powder was assessed as a part of organoleptic characteristics.

Microbial profile assessment of banana powder

Microbial study was conducted on the developed powder for a period of 90 days. The microbial assay for the banana powder were conducted in the Mycology Research Section, Department of Plant Pathology, Assam Agricultural University, Jorhat by following standard protocol and methodologies.

\section{Results and Discussion}

Physico chemical properties of banana powder across storage

Table 1 and fig 1a-1e shows the proximate analysis of the spray dried banana powder for the period of 3 months in terms of moisture, titratable acidity, non-enzymatic browning, reducing sugar and total sugar. Irrespective of the packaging methods, the moisture, NEB, total and reducing sugars of the banana powder progressively increased throughout the storage period, whereas the acidity decreased.

A study on investigating the effect of packaging materials and storage conditions on quality of capsicum (red and yellow) dried using microwave drying by Swain et.al. (2013) showed that the samples were heat sealed and packaged in: polypropylene (PP), Laminated Aluminum (Al) and High density polyethylene (HDPE). Then, these were stored at ambient atmosphere for four month and at every fifteen days, the quality parameters such as browning index (BI), total color difference (TCD), water activity (Aw), moisture content (MC), total carotenoid (TC) and Sensory Score (SS) were measured. The result indicated that storage period had significant effect $(\mathrm{P}<0.05)$ on response variables after 45 60 days of storage except sensory score. Laminated Aluminum (Al) was least affected by the ambient environment followed by HDPE and PP having low water vapor transmission rate (WVTR).

\section{Moisture}

When food product is exposed to an environment above or below this equilibrium point, the protective packages and its barrier level will determine how much the food will be impacted. Moisture content of the powder did not show any significant change at 0 and 30 days of storage in all the three types of packaging materials. However, a significant increase in the moisture content was observed at $60(\mathrm{~F}=9.50)$ and $90(\mathrm{~F}=15.05)$ days of storage at $5 \%$ level of significance in all the three types of packaging materials. Therefore, it can be opined that the optimized banana powder could be stored upto 30 days in all the three types of packaging materials without moisture uptake, aluminium foil laminated pouch thereby exhibiting as the best packaging material among all (Fig. 1a).

This finding is in agreement with the work done by Kumar and Mishra (2004) on mango fruit. They reported that the moisture content of mango soy fortified yoghurt powder during accelerated storage $\left(38 \pm 1^{\circ} \mathrm{C}\right.$ and $90 \pm 1 \%$ 
RH) gradually increased when packaged in high-density polypropylene (HDPP) and ALP.

Swain et al., (2013) in their study on the effect of packaging materials on quality characteristics of osmotically pretreated microwave assisted dried sweet pepper did not show any appreciable change in moisture content due to low water vapor transmission rate compared to multilayer HDPE film.

\section{Reducing sugar and total sugar}

The reducing sugar of the banana powder across storage increased from $24.98 \mathrm{~g}$ to 26.88 $\mathrm{g}, 25.08 \mathrm{~g}$ to $25.88 \mathrm{~g}$ and $24.98 \mathrm{~g}$ to $28.40 \mathrm{~g}$ in AFLP, HDPE and LDPE pouches respectively. However, the increase was not statistically significant.

As of total sugar content, the increase in AFLP, HDPE and LDPE were $188.40 \mathrm{~g}$ to $195.52 \mathrm{~g}, 188.38 \mathrm{~g}$ to $194.66 \mathrm{~g}$ and $188.48 \mathrm{~g}$ to $193.88 \mathrm{~g}$ respectively. But a statistically significant increase was observed at 90 days $(\mathrm{F}=4.08)$ only, the highest increase being exhibited by aluminium foil laminated pouch. Thus, it can be concluded that total sugar content was not affected till 60 days of storage whereas reducing sugar content of the banana powder was not affected during the entire storage period in all the three types of packaging material (Fig. 1d and 1e).

The increase in reducing and total sugars of banana powder during storage is attributed due to polysaccharide hydrolysis and non-reducing sugar inversion of the powdered sample.

\section{Titratable acidity}

The acidity of the banana powder declined in all the three types of packaging materials across storage, though a statistically significant difference was not observed. Acidity decreased from 3.66 to 2.90 per cent in aluminium foil laminated pouch, whereas it declined from 3.36 to 2.34 per cent and 3.34 to 2.30 per cent in HDPE and LDPE respectively starting from 0 days and ending in 90 days of storage (Fig. 1b).

However, the decrease in acidity during storage could be attributed due to the increase in reducing sugars and pick up of moisture by the powder.

\section{Non enzymatic browning}

Browning index too did not show a significant change across storage in all the three types of packaging materials, yet there was an increase in the browning of the product across storage. The browning of the optimized spray dried banana sample increased gradually across storage in all the three types of packaging materials. However, least degree of browning index was observed in aluminium foil laminated pouch. But high density polyethylene and low density polyethylene recorded increase in the browning index. Beyond 90 days of storage, the products were not acceptable considering the increase in the non-enzymatic browning (Fig. 1c).

The increase in non-enzymatic browning of banana powder during storage was due to the increase in moisture uptake by the product.

\section{Organoleptic analysis of banana powder across storage}

Organoleptic properties of the banana powder in terms of taste, flavor, colour, texture and overall acceptability were assessed during the entire storage period of 90 days. The organoleptic scores of the banana powder gradually declined during the entire storage period (Table 2) and (Fig. 2a-2e). Taste and flavor did not have significant effect in all the three types of packaging materials across storage. 
Table.1 Physicochemical changes of spray dried banana powder in different packaging materials across storage

\begin{tabular}{|c|c|c|c|c|c|}
\hline \multirow[t]{3}{*}{ Parameters } & \multirow{3}{*}{$\begin{array}{c}\text { Types of } \\
\text { packaging } \\
\text { material }\end{array}$} & \multicolumn{4}{|c|}{ Days from packaging } \\
\hline & & 0 days & 30 days & 60 days & 90 days \\
\hline & & Mean & Mean & Mean & Mean \\
\hline \multirow[t]{5}{*}{ Moisture } & AFLP & 2.00 & 1.90 & 2.10 & 2.10 \\
\hline & HDPE & 2.30 & 2.52 & 3.90 & 3.50 \\
\hline & LDPE & 2.40 & 2.26 & 3.20 & 2.70 \\
\hline & $\mathrm{F}$ & 2.60 & 2.82 & 9.50 & 15.05 \\
\hline & CD & 0.33 & 0.47 & 0.74 & 0.67 \\
\hline \multirow{5}{*}{$\begin{array}{l}\text { Titratable } \\
\text { acidity }\end{array}$} & AFLP & 3.66 & 3.24 & 3.14 & 2.90 \\
\hline & HDPE & 3.36 & 2.92 & 2.98 & 2.34 \\
\hline & LDPE & 3.34 & 3.42 & 2.74 & 2.30 \\
\hline & $\mathrm{F}$ & 1.19 & 1.90 & 1.91 & 2.08 \\
\hline & CD & 0.41 & 0.46 & 0.37 & 0.59 \\
\hline \multirow[t]{5}{*}{ NEB } & AFLP & 0.04 & 0.04 & 0.04 & 0.04 \\
\hline & HDPE & 0.04 & 0.04 & 0.04 & 0.04 \\
\hline & LDPE & 0.04 & 0.04 & 0.04 & 0.09 \\
\hline & $\mathrm{F}$ & 0.46 & 1.33 & 0.79 & 0.95 \\
\hline & $\mathrm{CD}$ & 0.005 & 0.004 & 0.003 & 0.08 \\
\hline \multirow{5}{*}{$\begin{array}{l}\text { Reducing } \\
\text { sugar }\end{array}$} & AFLP & 24.98 & 25.24 & 26.78 & 26.88 \\
\hline & HDPE & 25.08 & 25.74 & 27.04 & 25.88 \\
\hline & LDPE & 24.98 & 25.88 & 26.96 & 28.40 \\
\hline & $\mathrm{F}$ & 0.06 & 1.83 & 1.93 & 3.91 \\
\hline & $\mathrm{CD}$ & 0.65 & 0.63 & 0.24 & 1.62 \\
\hline \multirow[t]{5}{*}{ Total sugar } & AFLP & 188.40 & 190.60 & 193.98 & 195.52 \\
\hline & HDPE & 188.38 & 192.14 & 192.66 & 194.66 \\
\hline & LDPE & 188.48 & 192.24 & 192.46 & 193.88 \\
\hline & $\mathrm{F}$ & 0.0096 & 2.05 & 3.38 & 4.08 \\
\hline & $\mathrm{CD}$ & 1.36 & 1.62 & 1.132 & 1.02 \\
\hline
\end{tabular}

$\mathrm{F}_{\text {tab }} \quad$ at $5 \%=3.89$

at $1 \%=6.93$ 
Table.2 Organoleptic changes of spray dried banana powder in different packaging materials across storage

\begin{tabular}{|c|c|c|c|c|c|c|}
\hline \multirow{3}{*}{$\begin{array}{l}\text { Days from } \\
\text { Packaging }\end{array}$} & \multirow{3}{*}{$\begin{array}{c}\text { Types of } \\
\text { Packaging } \\
\text { material }\end{array}$} & \multicolumn{5}{|c|}{ Organoleptic Parameters } \\
\hline & & Taste & Colour & Flavour & Texture & $\begin{array}{c}\text { Overall } \\
\text { acceptability }\end{array}$ \\
\hline & & Mean \pm SD & Mean \pm SD & Mean \pm SD & Mean \pm SD & Mean士SD \\
\hline \multirow[t]{5}{*}{0 days } & AFLP & 3.20 & 5.80 & 5.80 & 6.80 & 5.80 \\
\hline & HDPE & 3.00 & 5.80 & 5.80 & 7.00 & 6.20 \\
\hline & LDPE & 3.00 & 5.80 & 5.40 & 6.80 & 6.60 \\
\hline & $\mathrm{F}$ & 1.00 & 0.00 & 0.67 & 0.50 & 3.42 \\
\hline & $\mathrm{CD}$ & 0.29 & 0.50 & 0.71 & 0.41 & 0.54 \\
\hline \multirow[t]{5}{*}{30 days } & AFLP & 3.20 & 6.20 & 5.80 & 6.80 & 5.80 \\
\hline & HDPE & 3.00 & 6.00 & 5.40 & 7.20 & 5.40 \\
\hline & LDPE & 3.20 & 6.00 & 5.20 & 6.20 & 4.80 \\
\hline & $\mathrm{F}$ & 0.50 & 0.16 & 1.17 & 6.33 & 0.25 \\
\hline & $\mathrm{CD}$ & 0.41 & 0.71 & 0.71 & 0.50 & 1.01 \\
\hline \multirow[t]{5}{*}{60 days } & AFLP & 2.60 & 5.40 & 5.00 & 6.00 & 4.80 \\
\hline & HDPE & 2.20 & 5.20 & 5.20 & 4.00 & 4.80 \\
\hline & LDPE & 2.00 & 4.80 & 4.8 & 4.20 & 4.80 \\
\hline & $\mathrm{F}$ & 2.80 & 1.16 & 0.43 & 5.86 & 0.28 \\
\hline & $\mathrm{CD}$ & 0.46 & 0.71 & 0.77 & 1.16 & 0.54 \\
\hline \multirow[t]{5}{*}{90 days } & AFLP & 2.20 & 5.60 & 4.80 & 4.40 & 4.40 \\
\hline & HDPE & 2.00 & 5.60 & 4.40 & 3.20 & 4.60 \\
\hline & LDPE & 2.00 & 5.60 & 4.20 & 3.00 & 4.20 \\
\hline & $\mathrm{F}$ & 5.56 & 5.65 & 0.64 & 5.73 & 0.75 \\
\hline & CD & 0.62 & 0.62 & 0.96 & 0.79 & 0.58 \\
\hline
\end{tabular}

Table.3 Microbiological changes of spray dried banana powder in different packaging materials across storage

\begin{tabular}{|c|c|c|c|c|c|}
\hline \multirow{3}{*}{$\begin{array}{c}\text { Types of } \\
\text { packaging } \\
\text { material }\end{array}$} & \multirow{4}{*}{$\begin{array}{l}\text { Observation } \\
\text { time }\end{array}$} & \multicolumn{4}{|c|}{ cfu $\mathrm{ml}^{-1} \times 10^{-6}$ dilution } \\
\hline & & \multicolumn{4}{|c|}{ Days from packaging } \\
\hline & & 0 days & 30 days & 60 days & 90 days \\
\hline & & Mean & Mean & Mean & Mean \\
\hline AFLP & 48 hours & 0.00 & 2.40 & 3.00 & 3.60 \\
\hline HDPE & 48 hours & 0.20 & 3.00 & 4.20 & 4.00 \\
\hline LDPE & 48 hours & 0.40 & 5.00 & 7.20 & 6.40 \\
\hline \multicolumn{2}{|c|}{ F value } & 0.6000 & 4.7931 & 7.8876 & 3.4059 \\
\hline \multicolumn{2}{|c|}{ CD } & 0.6507 & 1.5671 & 1.9412 & 2.068 \\
\hline
\end{tabular}

$\mathrm{F}_{\text {tab }} \quad$ at $5 \%=3.89$

at $1 \%=6.93$ 


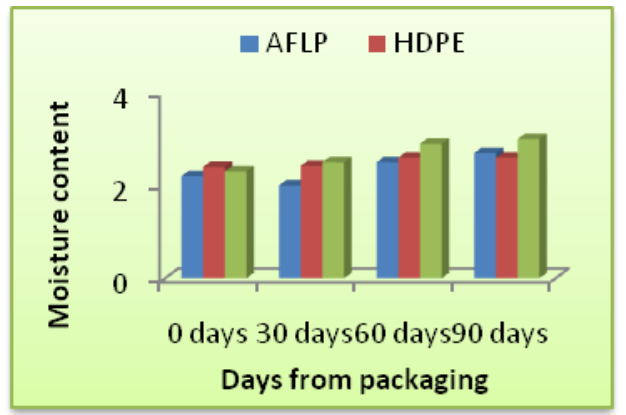

Fig. 1(a)

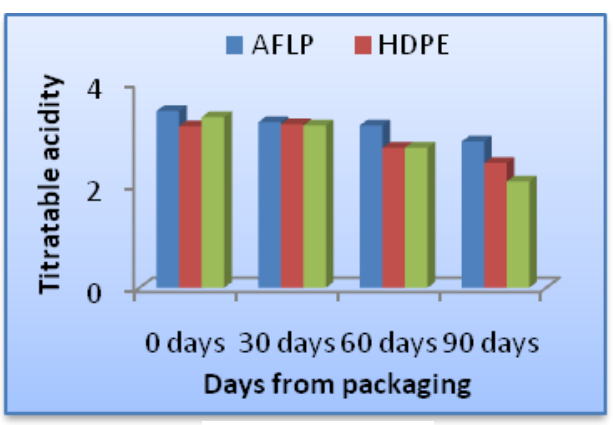

Fig. 1(b)

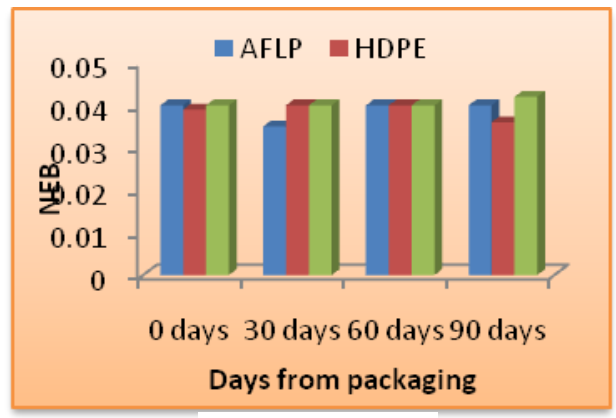

Fig. 1(c)

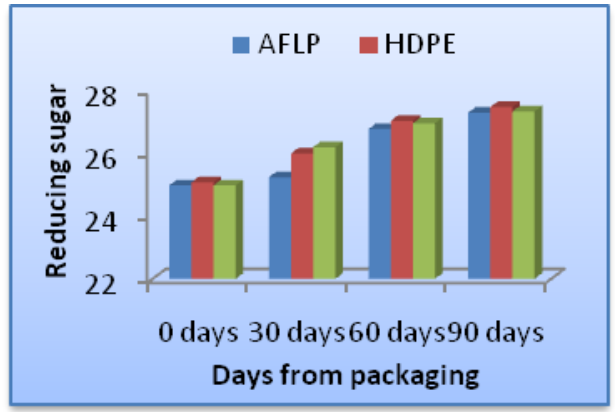

Fig. 1(d)

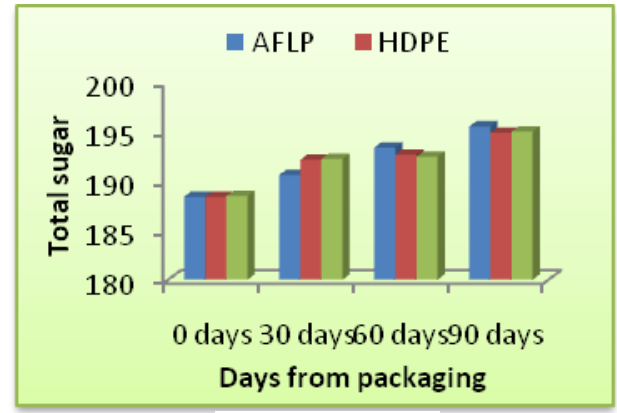

Fig. 1(e)

FIG. 1(a-e). CHANGES IN PHYSICOCHEMICAL PARAMETERS OF SPRAY DRIED BANANA POWDER IN DIFFERENT PACKAGING MATERIALS ACROSS STORAGE 


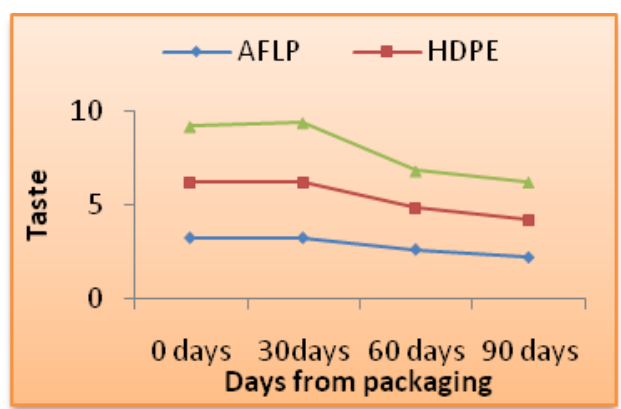

Fig. 2(a)

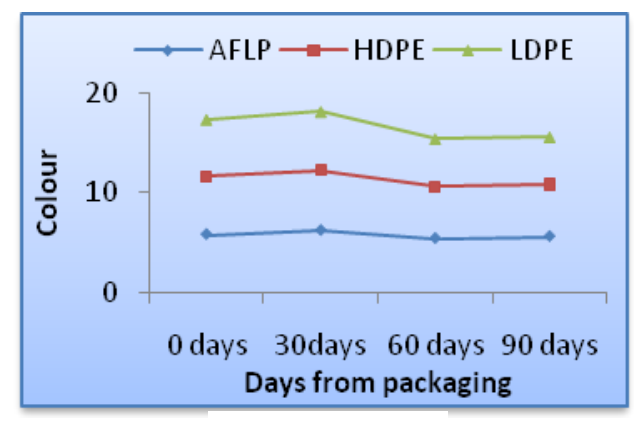

Fig. 2(b)

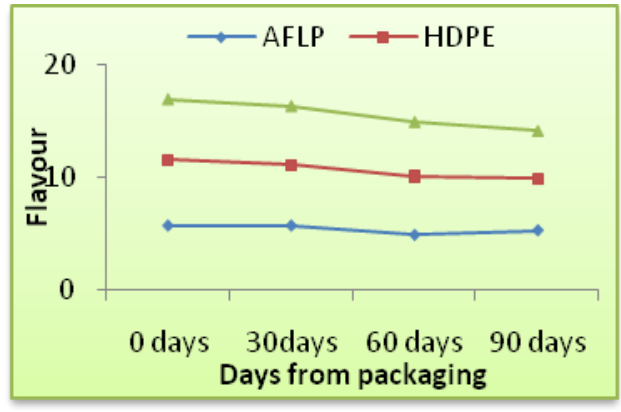

Fig. 2(c)

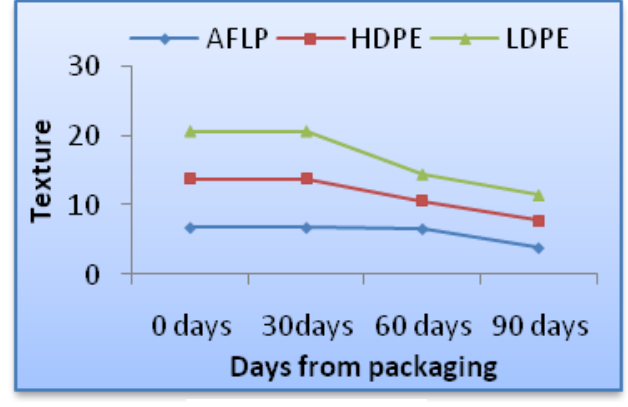

Fig. 2(d)

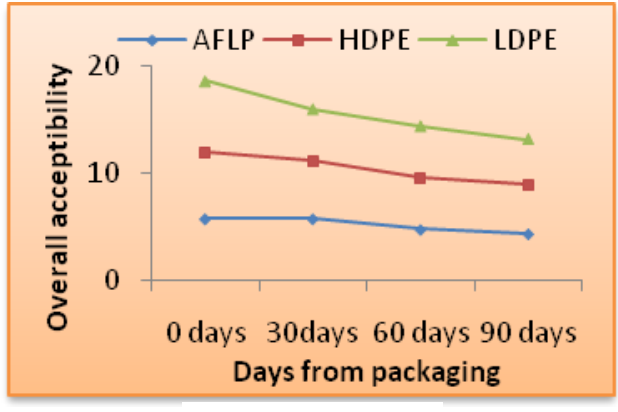

Fig. 2(e) 
Colour had a significant effect $(\mathrm{F}=5.56)$ on the storability of the banana powder at 90 days of storage. Thus, it can be opined that colour degraded beyond 90 days of storage in all the three types of packaging materials.

Texture of the optimized banana powder showed a significant change from 30 days of storage in all the three types of packaging materials $(\mathrm{F}=6.33)$. It can be justified by the fact that caking occurred in all the three types of packaging materials from 30 days of storage. The mean scores overall acceptability however did not show any significant change across storage.

As reported by Evelin et al., (2007) in a study conducted on packaging and storage studies on spray dried ripe banana powder under ambient conditions, banana powder packed in aluminium foil laminated pouches remained organoleptically acceptable for one year whereas, those packed in metallised polyester pouches remained acceptable for only 3 months.

In their study, the higher colour and flavor scores in vacuum packed samples were due to lesser browning and retention of flavor compounds under vacuum. Nitrogen packed samples showed the highest scores for texture. The lesser moisture and elimination of air by the inert nitrogen maintained the texture of the powder particles. But texture in vacuum packs deteriorated due to compression of the powder particles into a hard mass which affected the flowability, texture and visual appeal. In this regard, Ranganna (2009) stated that vacuum packaging was not advisable for fruit powders due to compression and caking of the fruit powders.

However, modified atmospheric packaging techniques were not employed for packing the spray dried banana powder sample in the present study.
Evelin et al., (2007) in their study on packaging and storage studies on spray dried ripe banana powder opined that nitrogen packs were better in terms of colour, flavour and texture retention, since nitrogen packing effectively delayed the onset of deteriorative auto oxidation reaction. Sagar et al., (1999) also observed that nitrogen packed dehydrated ripe mango slices retained the colour and quality during storage under ambient conditions.

\section{Microbial study of banana powder across storage}

The microbial load of the spray dried banana powder were analysed for a period of 90 days starting from 0 days of preparation at an interval of 30 days. The results are presented in Table 3. The findings of the study revealed significant increase in the microbial load in banana powder from 30 days of storage at $5 \%$ probability level upto 90 days. At 0 days the cfu count depicted non-significant increase among all the three types of packaging materials.

At 30 days, microbial load was found to increase significantly $(\mathrm{F}=4.7931)$ from 0 to $0.40 \times 10^{-6} \mathrm{cfu} / \mathrm{ml}$ at $5 \%$ probability level in all the 3 packaging materials, aluminium foil laminated pouch being the best packaging material owing to low cfu count.

Significant increase in microbial load was observed at 60 days $(\mathrm{F}=7.8876)$ and 90 days $(\mathrm{F}=3.4059)$, where AFLP too exhibited low microbial count. It can therefore be opined that aluminium foil laminated pouch was the best packaging material owing to lower microbial count.

However, comparing with the FSSAI standards for permissible limits of microbial count for dehydrated products, the microbial load in the present study was much higher 
than the FSSAI standard of 40,000cfu/ ml. This may be attributed due to the fact that right from recovering the powder to handling and packing was done at room conditions. Since no modified atmospheric packaging methods were employed, contamination in the final product might have occurred which led to increase in the microbial count during storage.

Evelin et al., (2007) in their study on packaging and storage studies on spray dried ripe banana powder under ambient conditions found that moisture sorption behavior of the powder showed a sigmoidal pattern with critical point at 4.8 per cent moisture $(28 \%$ ERH) and danger point at 4.1 per cent moisture (23\% ERH). Banana powder had a shelf life of one year under ambient conditions, when packed in aluminium foil laminated pouches.

\section{Acknowledgement}

The author is thankful to Head, Dept. of Food Engineering Technology, Tezpur University for allowing to conduct the research work in the department. The author is also thankful to the other staff of the Dept. of Food Engineering Technology for their help rendered in conducting the research work in the department. Gratefulness and thanks is also rendered to the Head and all other staff of the Department of Food Science and Nutrition, Assam Agricultural University for providing all necessary help and assistance to conduct the research work.

\section{References}

A.O.A.C. (1975). Official Methods of Analysis. Association of Official Analytical Chemists. Washington, D.C.

Evelin, M.A.; Jacob, J.P. and Vijayananad, D. (2007). Packaging and storage studies on spray dried ripe banana powder under ambient conditions. Journal of Food Science Technol. 44(1): 16-21.

Hsu, C.; Chen, W.; Weng, Y. and Tseng, C. (2003). Chemical composition, physical properties, and antioxidant activities of yam flours as affected by different drying methods. Food Chem. 83: 85-92.

Kumar, P. and Mishra, H.N. (2004). Storage stability of mango soy fortified yoghurt powder in two different packaging materials: HDPP and ALP. J. Food Engg. 65: 569-576.

Li, M.; Slaughter, D.C. and Thompson, J.E. (1997). Optical chlorophyll sensing system for banana ripening. Postharvest Biol. Technol. 12(3): 273.

Mani, S.; Jaya, S. and Das, H. (2002). Sticky issues on spray drying of fruit juices. The Society for Engineering in Agricultural, food, and biological systems, Paper No. MBSK 02-2001, An ASAE Meeting Presentation, pp. 1-18.

Medicott, A.P.; Semple, A.J.; Thompson, A.J.; Blackbourne, H.R. and Thompson, A.K. (1992). Measurement of colour changes in ripening bananas and mangoes by instrumental, chemical and visual assessments. Trop. Agric. 69(2): 161-166.

Oyewole, O.A. (2012). Microorganisms Associated with Deterioration of Stored Banana Fruits. Front. Sci. 2(5): 86-91.

Ranganna, S. (2009). Hand book of Analysis and quality control for Fruits and Vegetable Products. Tata McGraw Hill Publ. Co. Ltd., New Delhi.

Rekha, C.; Poornima, G.; Manasa, M.; Abhipsa, V.; Devi, J.P.; Kumar, H.T.V.; Kekuda, T.R.P. (2012). Ascorbic acid, total phenol content and antioxidant activity of fresh juices of four ripe and unripe citrus fruits. Chem. Sci. Trans. 1: 303-310.

Sagar, V.R.; Khurdiya, D.S. and Balakrishnan, K.A. (1999). Quality of dehydrated ripe mango slices as 
affected by packaging material and mode of packaging. J. Food Sci. Technol. 36: 67-70.

Shaun, R. and Ferris, B. (1997). Improving storage life of plantain and banana. IITA Research Guide, 61, p. 21.

Surendranathan, K.K.; Ramaswamy, K.K.; Radhakrishna, P. and Nair, J.S. (2003). Value added products from ripe banana: banana juice and ripe banana powder. BARC Newsletter Issue No. 249, Founder's Day Special Issue 188.

Swain, S.; Samuel, D.V.K. and Kar, A. (2013). Effect of packaging materials on quality characteristics of osmotically pretreated microwave assisted dried sweet pepper (Capsicum annum L.). J. Food Proc. Technol. 4: 264.

\section{How to cite this article:}

Nimi Barooah, Pranati Das, Mridula Saikia Barooah, Dibya Kant Seth and Pranab Dutta. 2018. Storage Studies on Spray Dried Ripe Banana Powder Produced by Response Surface Methodology. Int.J.Curr.Microbiol.App.Sci. 7(06): 1922-1933. doi: https://doi.org/10.20546/ijcmas.2018.706.228 